\title{
Estrogen receptor splice variants as a potential source of false-positive estrogen receptor status in breast cancer diagnostics
}

\author{
Floris H. Groenendijk • Wilbert Zwart • \\ Arno Floore $\cdot$ Stephanie Akbari $\cdot$ Rene Bernards
}

Received: 30 June 2013/Accepted: 18 July 2013/Published online: 4 August 2013

(C) The Author(s) 2013. This article is published with open access at Springerlink.com

\begin{abstract}
It is well established that only estrogen receptor (ER)-positive tumors benefit from hormonal therapies. We hypothesized that a subgroup of breast cancer patients expresses estrogen receptor $\alpha(\mathrm{ER} \alpha)$, but fails to respond to hormonal therapy due to the expression of a non-functional receptor. We analyzed a series of 2,658 ER $\alpha$-positive HER2-negative breast tumors for ER $\alpha$ and progesterone receptor (PR) status as determined by mRNA expression and for their molecular subtypes (Luminal type vs Basal type, assessed by BluePrint ${ }^{\mathrm{TM}}$ molecular subtyping assay). In addition, we assessed the recurrence risk (low vs high) using the 70 -gene MammaPrint ${ }^{\mathrm{TM}}$ signature. We found that 55 out of 2,658 (2.1\%) tumors that are ER $\alpha$ positive by mRNA analysis also demonstrate a Basal molecular subtype, indicating that they lack expression of estrogenresponsive genes. These ER $\alpha$-positive Basal-type tumors
\end{abstract}

Electronic supplementary material The online version of this article (doi:10.1007/s10549-013-2648-1) contains supplementary material, which is available to authorized users.

F. H. Groenendijk · R. Bernards ( $\square$ )

Division of Molecular Carcinogenesis, Cancer Genomics Centre,

The Netherlands Cancer Institute, Plesmanlaan 121, 1066 CX,

Amsterdam, The Netherlands

e-mail: r.bernards@nki.nl

W. Zwart

Division of Molecular Pathology, The Netherlands Cancer Institute, Plesmanlaan 121, 1066 CX, Amsterdam, The

Netherlands

A. Floore $\cdot$ R. Bernards

Department of Research and Development, Agendia NV,

Amsterdam, The Netherlands

S. Akbari

Center for Breast Health, Virginia Hospital Center, Arlington,

VA, USA express significantly lower levels of both ER $\alpha$ and PR mRNA as compared to Luminal-type tumors $(P<0.0001)$ and almost invariably ( $94.5 \%$ ) have a high-risk MammaPrint $^{\mathrm{TM}}$ profile. Twelve of the MammaPrint ${ }^{\mathrm{TM}}$ genes are directly ER $\alpha$ responsive, indicating that MammaPrint ${ }^{\mathrm{TM}}$ assesses ER $\alpha$ function in breast cancer without considering $E R \alpha$ mRNA levels. We find a relatively high expression of the dominant negative ER $\alpha$ splice variant $\mathrm{ER} \Delta 7$ in $\mathrm{ER} \alpha$ positive Basal-type tumors as compared to ER $\alpha$-positive Luminal-type tumors $(P<0.0001)$. Expression of the dominant negative $\mathrm{ER} \alpha$ variant $\mathrm{ER} \Delta 7$ provides a rationale as to why tumors are of the Basal molecular subtype while staining ER $\alpha$ positive by immunohistochemistry. These tumors may lack a functional response to estrogen and consequently may not respond to hormonal therapy. Our data indicate that such patients are of MammaPrint ${ }^{\mathrm{TM}}$ high recurrence risk and might benefit from adjuvant chemotherapy.

Keywords Breast cancer - Estrogen receptor variants · Intrinsic subtypes · Molecular subtypes . Tamoxifen

\section{Introduction}

The female hormone estradiol (E2) is a potent mitogen for estrogen receptor $\alpha(\mathrm{ER} \alpha)$-positive breast cancers. Hence, $\mathrm{ER} \alpha$ protein levels, as determined by immunohistochemistry (IHC), are strongly predictive for response to endocrine therapies [1]. $75 \%$ of all breast cancers express ER $\alpha$, but not all tumors that express this steroid receptor respond to hormonal therapies. ER $\alpha$ is a member of the nuclear hormone receptor gene family that regulates transcription in a hormone-dependent fashion through sequence-specific 
DNA binding [2]. Indeed, ER $\alpha$ binding sites are found proximal to many genes and consequently estrogen stimulation of breast cancer cells leads to significant changes in cellular gene expression [3, 4]. These responsive genes include the progesterone receptor (PR), one of the bestcharacterized ER $\alpha$ target genes. Hence, the PR is often coexpressed with ER $\alpha$ in breast cancers and PR testing is commonly performed in conjunction with ER $\alpha$ testing to assess hormone receptor status of a breast tumor. However, PR status is not a strong predictor of response to endocrine therapy, indicating that PR expression is not solely controlled by ER $\alpha$ activity [5].

Over a decade ago, the first large-scale gene expression profiling studies in breast cancer demonstrated that breast cancers consist of a number of "intrinsic" or "molecular" subtypes that are characterized by similarities in gene expression patterns [6]. Among these intrinsic subtypes are the "Luminal" and "Basal" tumors, which are thought to represent primarily ER-positive and -negative tumors, respectively. Consistent with this view, it was demonstrated that BluePrint ${ }^{\mathrm{TM}}$, an 80-gene mRNA expression signature that identifies Luminal and Basal tumors, is significantly enriched in bona fide ER target genes [7]. These data suggest that this intrinsic subtype signature primarily measures the functionality of the ER, as judged by expression of its downstream target genes. As such, this signature also has the potential to identify a subgroup of breast cancer patients who are ER $\alpha$ positive by IHC and/or mRNA expression, but fail to elicit the hormone-induced transcriptional responses that normally result from ER stimulation (ER $\alpha$ target genes "off"; Basal type). Such a scenario would imply that breast cancers having this phenotype express a dysfunctional ER $\alpha$ protein that can nevertheless be detected by IHC.

Several different ER $\alpha$ variant mRNAs have been described in human breast cancer. Almost all of these naturally occurring variants are mRNA splicing variants, in which one or more exons are absent from the ER $\alpha$ mRNA. In most $E R \alpha$ splicing variants, except for variants lacking exon 3 or 4 , translation runs out of frame after the site of the splicing variation, leading to a truncated protein [8-12]. Since the antibodies for ER $\alpha$ used in IHC often include those that recognize an epitope encoded by the first exon of the ER $\alpha$ gene [13], such splice variants are likely detected as IHC positive for ER $\alpha$, even though their function may be different from the normal ER $\alpha$ protein. The functional activity of these variant $\mathrm{ER} \alpha$ proteins can be negative, dominant negative, or dominant active on ER $\alpha$ target genes. Dominant negative variants are not only inactive themselves but also inactivate wild-type ER $\alpha$ through heterodimerization. Two variants, the ER $\Delta 3$ and the ER $\Delta 7$ variants, have been described as dominant negative receptor forms in the presence of wild-type ER $\alpha$ [8-12]. The ER $\Delta 7$ mRNA has been reported to be the major alternatively spliced form in most human breast tumors and cancer cell lines [14]. The ER $\Delta 7$ is especially interesting because the hormone-binding domain, the transcription activation function-2 domain, and the dimerization domain are all partially located in exon 7 (Fig. 1). It has been shown that the ER $\Delta 7$ variant has the ability to suppress the E2-dependent transcriptional activation by both wild-type ER $\alpha$ and ER $\beta$ [14].

According to the guideline recommendations from the American Society of Clinical Oncology (ASCO) and the College of American Pathologists (CAP) for IHC testing of $\mathrm{ER} \alpha$ and $\mathrm{PR}$ in breast cancer, it is recommended that ER $\alpha$ assays should be considered positive if there are at least $1 \%$ (weakly) positive tumor nuclei in the sample [13]. This threshold is based on a cut-point analysis correlating IHC scores with outcome in patients treated with adjuvant endocrine therapy alone, where patients with a score correlating to $1-10 \%$ weakly positive cells had a statistically significant better prognosis than patients with scores correlating with $<1 \%$ positive cells [15]. However, Iwamoto et al. have shown recently that only a minority of the borderline (1-9 \% positive nuclei) IHC ER $\alpha$-positive tumors are of the Luminal subtype (as identified by the PAM50 classifier [16]) and that most of these borderline ER $\alpha$ positive samples are of the Basal molecular subtype [17].

Here, we identify in a large cohort of molecular profiled breast cancers a subgroup of around $2 \%$ of breast tumors that are ER $\alpha$ positive by mRNA expression analysis, but are of the Basal molecular subtype. These tumors express significantly lower levels of both ER $\alpha$ and PR mRNA than the Luminal-type tumors and have almost invariably (94.5\%) a high-risk MammaPrint ${ }^{\mathrm{TM}}$ profile. Furthermore, we show that these tumors have relatively high levels of the dominant negative ER $\Delta 7$ splice variant, in agreement with the notion that they may lack a functional response to estrogen and consequently may not respond to hormonal therapy.

\section{Patients and methods}

Patient samples and molecular profiling

A total of 3,527 breast cancer patient specimens were retrospectively analyzed. This selection was based on the

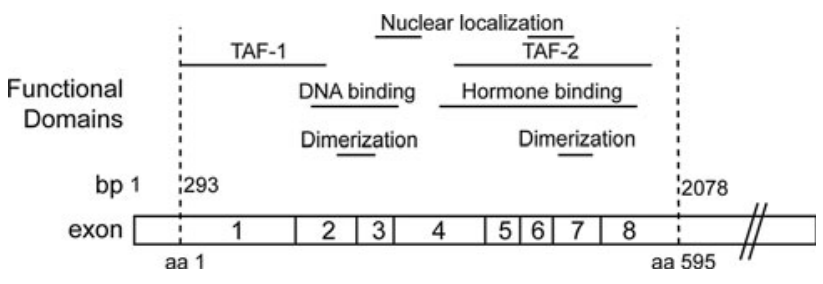

Fig. 1 Organization of the ER $\alpha$ mRNA and functional domains. $T A F-1$ transcription activation function $1, T A F-2$ transcription activation function 2, $a a$ amino acid, $b p$ base pair 
availability of MammaPrint ${ }^{\mathrm{TM}}$, TargetPrint ${ }^{\mathrm{TM}}$, and BluePrint $^{\mathrm{TM}}$ molecular profiling results as performed in the Agendia testing laboratories. The ER $\alpha$ status on mRNA levels was determined by TargetPrint, a microarray-based gene expression test, which offers a quantitative assessment of the patient's level of ER $\alpha$, PR, and HER2 expression [18]. The TargetPrint probe for ER $\alpha$ mRNA detection is located in the $3^{\prime}$ UTR region. The ER $\alpha, P R$, and HER2 TargetPrint score is a value between -1 and 1 , where the null cutoff value is calibrated to $1 \%$ IHC ER $\alpha$ positive cells, as identified in a reference laboratory according to ASCO/CAP guidelines. Tumors are reported ER $\alpha$ or PR positive when the TargetPrint score is above 0 , corresponding to $>1 \%$ IHC-positive cells [18]. Molecular subtyping was performed using the 80 -gene BluePrint ${ }^{\mathrm{TM}}$ molecular subtyping profile for the classification of breast cancer into Basal type, Luminal type, and ERBB2 type (HER2 positive) molecular subclasses [7]. In addition, the tumors were classified as low risk or high risk for distant recurrence using the 70 -gene MammaPrint ${ }^{\mathrm{TM}}$ signature, a FDA-cleared breast cancer recurrence assay, performed by Agendia Inc. [19].

\section{$\mathrm{ER} \Delta 7$ variant analysis}

We obtained RNA from 15 ER $\alpha$-positive Luminal-type tumors and from $12 \mathrm{ER} \alpha$-positive Basal-type tumors to analyze the relative ER $\Delta 7$ mRNA expression. cDNA was synthesized from $500 \mathrm{ng}$ RNA using SuperScript II Reverse Transcriptase (Invitrogen) with random hexamer primers. The total ER $\alpha$ and ER $\Delta 7$ mRNA expression was determined by qRT-PCR. For total ER $\alpha$ expression, the forward primer was located in exon 1 and the reverse primer in exon 2. For ER $\Delta 7$ expression, the forward primer was located in exon 6 and the reverse primer was designed to specifically detect ER $\Delta 7$ and located partially in exon 6 (12 nucleotides) and partially in exon 8 (14 nucleotides) (Primer sequences in Supplementary Materials). All qRTPCR reactions were performed in duplicates using SYBR Green reaction mix containing $5 \mu \mathrm{l}$ cDNA. The expression levels were quantified using a reference standard dilution curve. The relative expression of the ER $\Delta 7$ variant was calculated by dividing the ER $\Delta 7$ mRNA expression by the total ER $\alpha$ mRNA expression.

Identification of ER $\alpha$ target genes in the 70-gene MammaPrint $^{\mathrm{TM}}$ breast cancer signature

The 70 MammaPrint genes were analyzed for ER $\alpha$ binding events within $20 \mathrm{~kb}$ from the transcription start site (TSS), representing the most commonly detected window for ERmediated gene regulation [20]. ER $\alpha$-binding sites were identified by ChIP-seq analyses [21], using available datasets for the Luminal breast cancer cell line MCF-7 [22] and 2 ER-positive Luminal breast tumor samples (paper in submission; GSE40867). Publically available data on E2stimulated gene expression were used from [3], where Global Run-On sequencing was applied to assess gene transcription after 0-, 10-, 40-, and 160-min E2 treatment. Only genes with a differential expression as compared to control conditions with a false discovery rate of $\sim 0.1 \%$ were considered as E2 regulated.

\section{Results}

ER $\Delta 7$ splice variant expressed in an ER $\alpha$-positive basal-type breast cancer

We have recently developed an 80-gene signature (BluePrint $^{\mathrm{TM}}$ ) that identifies the three major intrinsic subtypes (Basal, Luminal, and HER2) of breast cancer [7]. Of these 80 genes, 58 are used to identify the Luminal subtype. Importantly, 32 out of these 58 Luminal subtype reporter genes have ER $\alpha$-binding sites adjacent to the TSS [7]. This indicates that the genes that identify Luminal-type breast cancer are significantly enriched for bona fide ER $\alpha$ target genes and suggests that the Luminal subtype is characterized by tumors that have a functional $\mathrm{ER} \alpha$ pathway. Conversely, BluePrint Basal-type tumors would be expected to have either no significant ER $\alpha$ expression or a non-functional ER $\alpha$ pathway; these same bona fide ER $\alpha$ target genes show an inverse expression pattern in Basal-type tumors [7].

Following argumentation as outlined above, one would expect that breast tumors that are ER $\alpha$ positive, but Basal type by BluePrint analysis, would either have a very low level of $\mathrm{ER} \alpha$ protein or harbor a defective $\mathrm{ER} \alpha$ protein. To test this hypothesis directly, we mined the Agendia database for patients who are $\mathrm{ER} \alpha$ positive by TargetPrint, but Basal type by BluePrint molecular subtype analysis. We initially identified a patient (Table 1, patient 1; 60-year-old woman with $9 \mathrm{~mm}$, moderately differentiated, HER 2 negative, ER/ PR $>90 \%$ by IHC, invasive ductal carcinoma), who had undergone MammaPrint, TargetPrint, and BluePrint tests. She had MammaPrint high-risk result, was ER/PR positive by TargetPrint, but Basal subtype by BluePrint, suggesting that the ER $\alpha$ was present both at the protein (IHC > $90 \%$ ) and mRNA levels, but that ER $\alpha$ target genes were not expressed in this tumor (hence Basal type). The tumor was also analyzed using the OncotypeDX ${ }^{\mathrm{TM}}$ breast cancer assay (Genomic Health Inc.), classifying the tumor as low risk for distant recurrence (Recurrence Score 8, Table 1).

We used the same tumor mRNA sample as was used to perform the MammaPrint, TargetPrint, and BluePrint assays for detailed analysis of the ER $\alpha$ mRNA transcript in this patient. We first PCR amplified the coding sequence of 


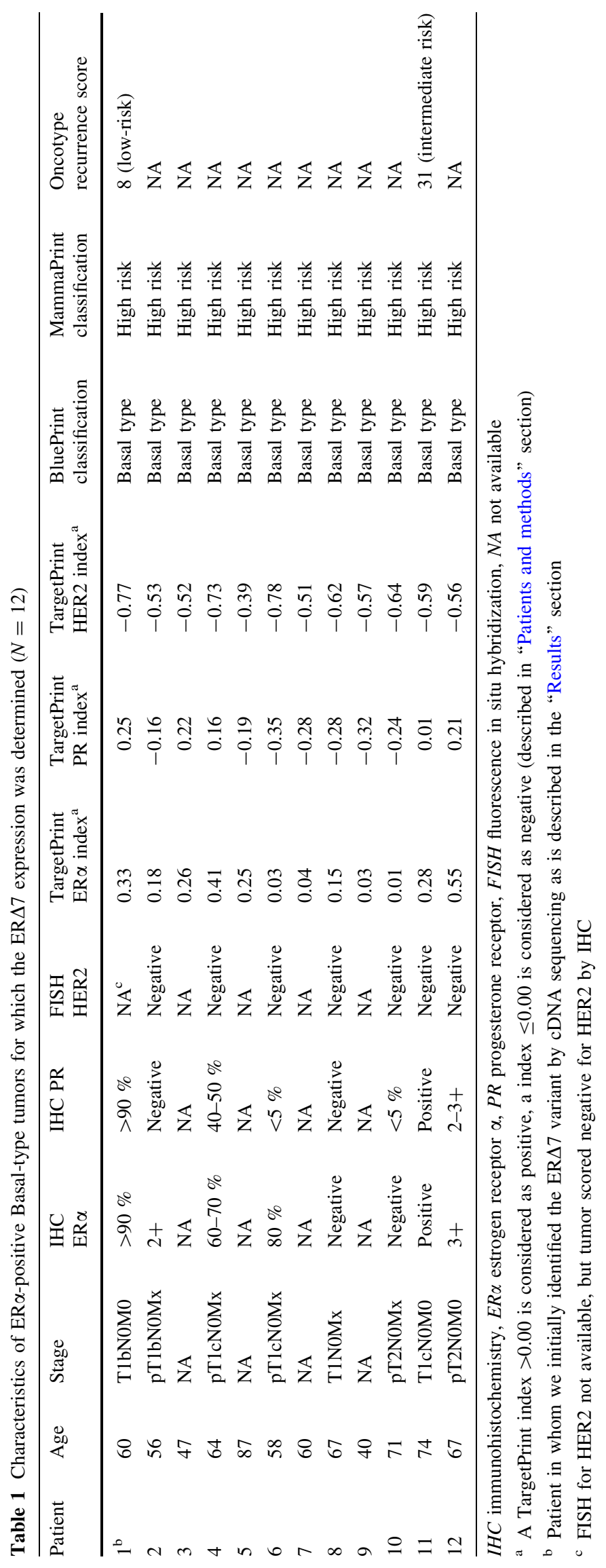


$\mathrm{ER} \alpha$ with specific oligonucleotides that span the start codon of ER $\alpha$ at the $5^{\prime}$ end and the stop codon at the $3^{\prime}$ end (Primer sequences in Supplementary Materials). Agarose gel electrophoresis of the PCR product revealed a smaller DNA fragment next to the expected DNA fragment coding for the open reading frame of ER $\alpha$. Inspection of the DNA sequence of the smaller product revealed an ER $\alpha$ sequencelacking exon 7 of the coding sequence (data not shown). This transcript corresponds to the previously reported $\mathrm{ER} \Delta 7$, an $\mathrm{ER} \alpha$ splice variant that inhibits the function of the normal (wild-type) ER $\alpha$ in a dominant fashion [14].

Frequency of ER $\alpha$-positive basal-type tumors

To determine the frequency at which ER $\alpha$-positive Basaltype breast tumors occur, we searched the Agendia database for additional cases. Out of 3,527 cases, we identified 2,658 ER $\alpha$-positive, HER2-negative breast tumors, as judged by TargetPrint mRNA expression, for which BluePrint intrinsic subtyping data were available. From these 2,658 tumors, 2,603 (97.9\%) were classified as Luminal type and 55 (2.1\%) were classified as Basal type (Table 2). The mean ER $\alpha$ and PR TargetPrint indices for the ER $\alpha$-positive Basal-type tumors were significantly lower than for the ER $\alpha$-positive Luminal-type tumors $(P<0.0001)$.

$\mathrm{ER} \Delta 7$ splice variant expression in ER $\alpha$-positive basaltype breast cancers

We further analyzed an additional 11 of these $55 \mathrm{ER} \alpha$ positive Basal-type tumors for expression of total ER $\alpha$ as well as the ER $\Delta 7$ variant by qRT-PCR. The specificity of the primer pairs was tested with cDNA from MCF7 breast cancer cells overexpressing either wild-type $\mathrm{ER} \alpha$ or ER $\Delta 7$ and the calculated ER $\Delta 7 /$ total ER $\alpha$ ratio was correlated with ER $\alpha$ protein expression in these cells. The ER $\alpha$ antibody clone 1D5 (Dako) was used for western blot analysis, for which the epitope is located in the $\mathrm{N}$-terminal domain of $E R \alpha$ and therefore recognizes both wild-type $\mathrm{ER} \alpha$ and ER $\Delta 7$. We show in these cells that the relative ER $\Delta 7$ levels as measured by qRT-PCR are highly concordant with protein expression (Supplementary Fig. 1).

The average total ER $\alpha$ mRNA expression by qRT-PCR was significantly lower for the 12 analyzed ER $\alpha$-positive Basal-type tumors compared to 15 randomly chosen ER $\alpha$ positive Luminal-type tumors (Fig. $2 \mathrm{a} ; P=0.0019$ ), consistent with the TargetPrint results (Table 2). There was no significant difference in average ER $\Delta 7$ mRNA expression between the ER $\alpha$-positive Basal-type and Luminal-type samples (Fig. 2b; $P=0.4088$ ). However, the relative ER $\Delta 7 \mathrm{mRNA}$ expression was significantly higher for the ER $\alpha$-positive Basal-type group compared to the ER $\alpha$-positive Luminal-type group (Fig. 2c; $P<0.0001$ ), due to the lower overall ER $\alpha$ mRNA expression in the Basal-type tumors.

The characteristics of the 12 ER $\alpha$-positive Basal-type tumors, for which ER $\Delta 7$ splice variant expression was determined, are shown in Table 1. For 8 of the 12 patients, we were able to retrieve the ER $\alpha$ and PR IHC scoring. Based on the ER $\alpha$ IHC, six out of eight $(75 \%)$ patients were classified as ER $\alpha$ positive. In two patients, we found a discrepancy between TargetPrint and ER $\alpha$ IHC classification; in one of these patients, the TargetPrint ER $\alpha$ index was just above the ER $\alpha$-positive threshold (patient 10). The PR IHC was in concordance with the PR classification based on TargetPrint in six of eight patients, and for two patients (patient 6 and 8), a small percentage of

Table 2 TargetPrint ER $\alpha / \mathrm{PR}$ index, PR classification, and MammaPrint classification of 2,658 ER $\alpha$-positive, HER2-negative tumors according to their BluePrint molecular subtype (Basal type vs Luminal type)

\begin{tabular}{|c|c|c|c|}
\hline & \multicolumn{2}{|l|}{ BluePrint classification } & \multirow{2}{*}{$P$ value } \\
\hline & Basal type $(n=55,2.1 \%)$ & Luminal type $(n=2,603,97.9 \%)$ & \\
\hline $\mathrm{ER} \alpha$ index $($ mean $\pm \mathrm{SD})$ & $0.20( \pm 0.15)$ & $0.57( \pm 0.17)$ & $<0.0001^{\mathrm{a}}$ \\
\hline $\mathrm{PR}$ index $($ mean $\pm \mathrm{SD})$ & $-0.04( \pm 0.27)$ & $0.28( \pm 0.31)$ & $<0.0001^{\mathrm{a}}$ \\
\hline PR classification & & & $<0.0001^{\mathrm{b}}$ \\
\hline PR positive & $24(43.6 \%)$ & $2047(78.6 \%)$ & \\
\hline PR negative & $31(56.4 \%)$ & $556(21.4 \%)$ & \\
\hline MammaPrint classification & & & $<0.0001^{\mathrm{b}}$ \\
\hline Low risk & $3(5.5 \%)$ & $1434(55.1 \%)$ & \\
\hline High risk & $52(94.5 \%)$ & $1169(44.9 \%)$ & \\
\hline
\end{tabular}

$E R \alpha$ estrogen receptor $\alpha, P R$ progesterone receptor, $S D$ standard deviation

${ }^{\text {a }}$ Unpaired $t$ test, two-tailed

b Fisher's exact test, two-tailed 

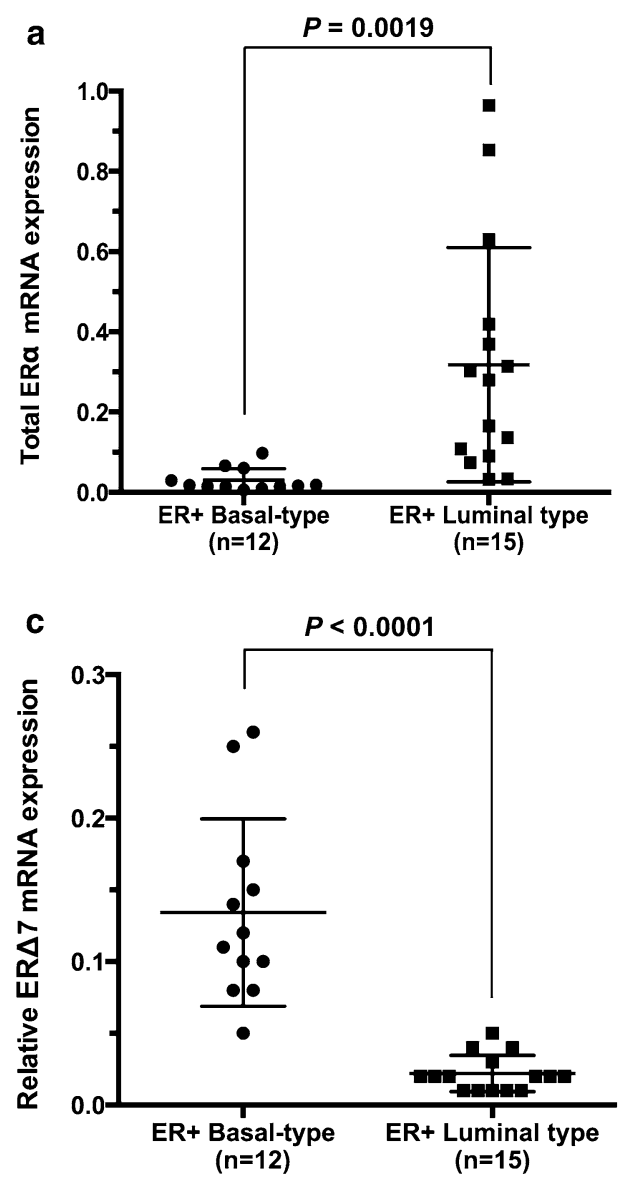

Fig. 2 ER $\alpha$-positive Basal-type tumors have a relatively high ER $\Delta 7$ expression compared to ER $\alpha$-positive Luminal-type tumors. a Scatter plot of total ER $\alpha$ mRNA expression analysis by qRT-PCR in ERpositive Basal-type $(n=12)$ and ER-positive Luminal-type $(n=15)$ tumors. The qRT-PCR primers are located in exon 1 and exon 2. Points indicate individual tumors; lines indicate mean with SD. b Scatter plot of specific ER $\Delta 7$ mRNA expression analysis by qRTPCR in ER-positive Basal-type $(n=12)$ and ER-positive Luminaltype $(n=15)$ tumors. The qRT-PCR Primers are located in exon 6

PR-positive cells was detected by IHC where the TargetPrint PR index was negative. The HER2 negative status was confirmed by fluorescence in situ hybridization (FISH) in all available cases. All patients (12/12) were stratified as high risk of distant recurrence by the MammaPrint prognostic gene signature.

MammaPrint measures ER $\alpha$ function independent of ER $\alpha$ expression

MammaPrint measures 70 genes that were selected from the entire complement of human genes, but ER $\alpha$ is not among the MammaPrint genes [23]. Nevertheless, we observed that 52 of the 55 (94.5\%) ER $\alpha$-positive Basaltype tumors were MammaPrint high risk, while only $44.9 \%$ of the ER $\alpha$-positive Luminal-type tumors were classified as high risk of recurrence (Table 2; $P<0.0001$ ).

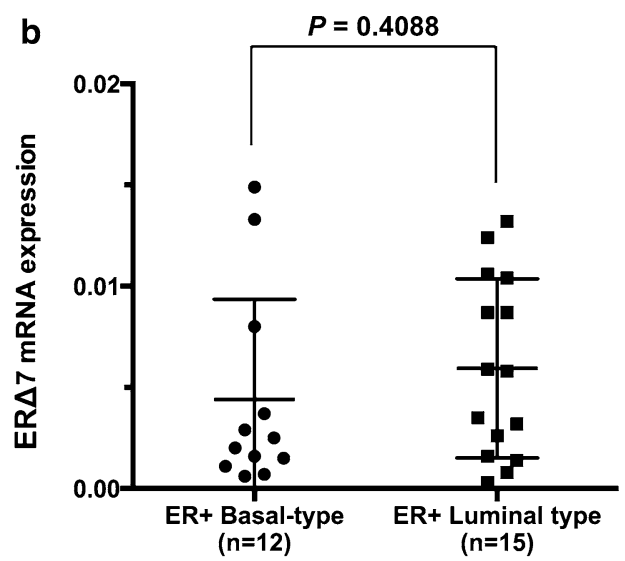

(forward) and over the exon 7 splice site (reverse). Points indicate individual tumors; lines indicate mean with SD. c Scatter plot of relative ER $\Delta 7$ expression calculated by dividing the ER $\Delta 7$ mRNA expression with the total $\mathrm{ER} \alpha$ mRNA expression in ER-positive Basal-type $(n=12)$ and ER-positive Luminal-type $(n=15)$ tumors. Points indicate individual tumors; lines indicate mean with SD. $P$ values are calculated by unpaired $t$ tests with Welch's correction and are two-tailed

Since the MammaPrint assay identifies nearly all these ER $\alpha$-positive Basal-type tumors as high risk, it suggests that the test measures ER $\alpha$ activity independent of the ER $\alpha$ mRNA expression level itself. To investigate this further, we determined how many of the 70 MammaPrint prognosis genes are directly responsive to E2 treatment. For this, a publically available dataset was used that assessed gene expression changes after 10, 40, and 180 min of E2 treatment [3]. We found that 16 MammaPrint reporter genes annotated in the most recent build of the human reference genome sequence are E2 regulated (Fig. 3a). Next, we tested whether these E2-responsive MammaPrint genes can be classified as direct ER $\alpha$ target genes. Using a publically available ChIP-seq dataset [22], the genome-wide chromatin-binding landscape of ER $\alpha$ in MCF7 cells was analyzed for the occurrence of an ER $\alpha$ binding event within 20,000 bp from the TSS of any of the MammaPrint genes. 

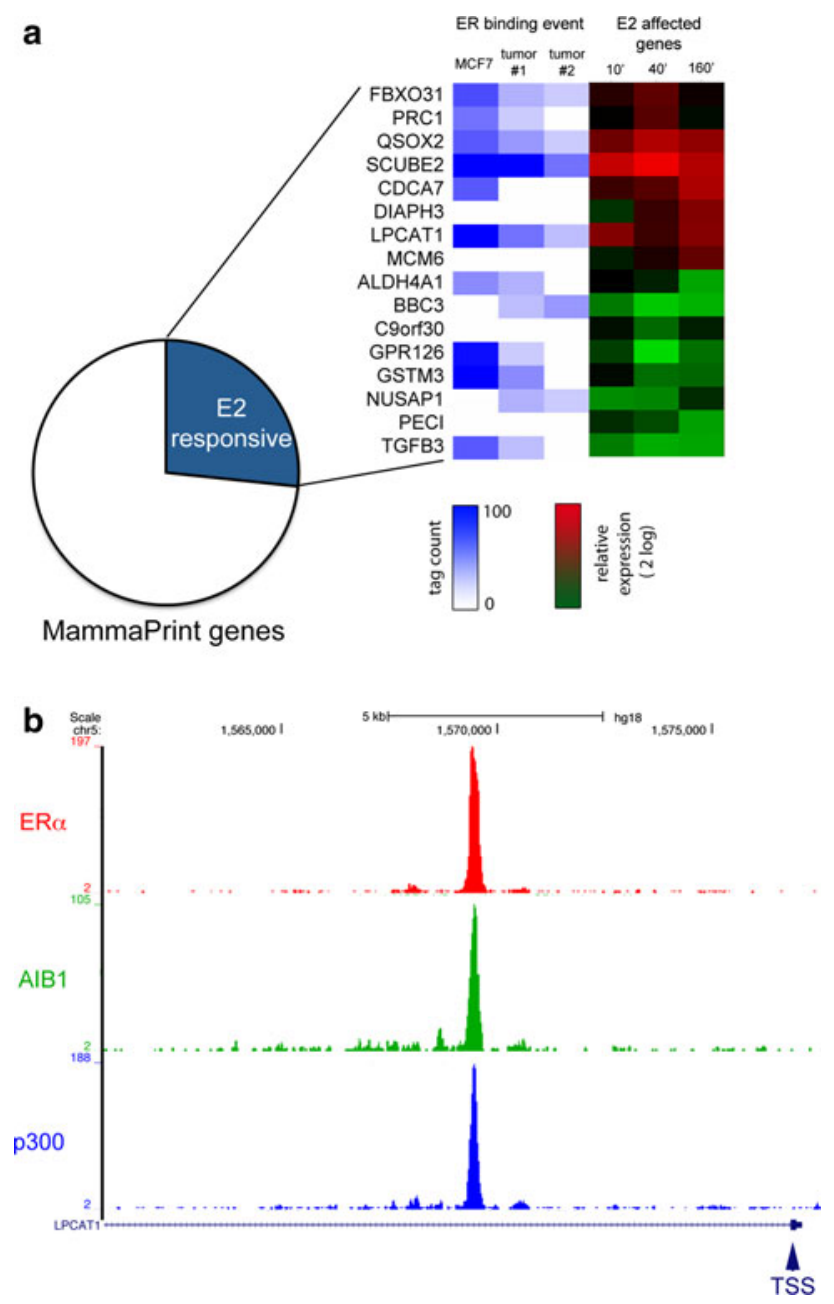

Fig. 3 Functional ER $\alpha$ target genes in MammaPrint 70-gene set. a Pie chart, depicting the proportion of MammaPrint genes, which are affected by E2 treatment. Heat map (right panel) depicts proximal ER $\alpha$ ChIP-seq signal by tag count (blue) as well as relative gene expression values as measured by GRO-seq, after 10, 40, and $160 \mathrm{~min}$ of E2 treatment (green-black-red heat map). b Genome browser snapshot, depicting a shared ER $\alpha$ (red), AIB1 (green), and p300 (blue) proximal to the LPCAT1 transcription start site. Chromosome number, genomic coordinates, and tag count are indicated

This window was chosen since most ER $\alpha$-mediated gene regulation is found within this distance from a TSS [20]. Ten out of 16 genes had an ER $\alpha$ binding event within 20,000 bp from the TSS (Fig. 3a), as exemplified for the LPCAT1 locus (Fig. 3a). Importantly, the essential ER $\alpha$ coactivators AIB1 (also known as SRC3) and p300 were also present at this specific binding site, indicating that $\mathrm{ER} \alpha$ is likely to be functional here [24]. Furthermore, we confirmed that ER $\alpha$ binding events in E2-regulated MammaPrint genes are also found in 2 ER-positive Luminal human breast tumor samples, for which ER $\alpha$ ChIP-seq data are available (Fig. 3a). In total, 12 out of 16 E2-regulated genes had an ER $\alpha$-binding site in either MCF7 cells or in the two studied tumors (Fig 3a). Cumulatively, these data indicate that bona fide ER $\alpha$ target genes are enriched in the MammaPrint gene signature, providing a plausible explanation for why the MammaPrint can measure ER $\alpha$ functionality rather than its mere presence, in contrast to other available assays.

\section{Discussion}

The present study identifies approximately 1 in 50 ERpositive breast cancer patients as Basal molecular subtype. Basal-type breast tumors are characterized by an absence of expression of ER $\alpha$ target genes, which is generally thought to result from the absence of ER $\alpha$ expression [25]. However, the group of tumors identified here is ER $\alpha$ positive on the mRNA level, suggesting that their Basal phenotype is the result of a lack of ER $\alpha$ protein expression or a lack of functionality of the ER $\alpha$ protein present in these tumors. Indeed, we find that these tumors not only express relatively low levels of ER $\alpha$ mRNA but also express a splice variant of ER $\alpha$-missing exon 7 (ER $\Delta 7$, Fig. 2a, b). This ER $\alpha$ variant has been shown previously to act in a dominant negative fashion, meaning that this variant can inhibit the function of the wild-type ER $\alpha$ protein when co-expressed in the same cell [14]. We note that the absolute levels of ER $\Delta 7$ are comparable in ER $\alpha$-positive Basal-type versus ER $\alpha$-positive Luminal-type tumors, but that the relative abundance of $\mathrm{ER} \Delta 7$ is higher in the $\mathrm{ER} \alpha$ positive Basal-type tumors (Fig. 2c). We interpret these data as follows: When the levels of wild-type ER $\alpha$ in a breast tumor are high, the inhibitory effects of dominant negative ER $\Delta 7$ are by comparison minor, leaving the cell with considerable ER $\alpha$ activity and thus with a luminal phenotype (Fig. 4, right). In contrast, lower levels of wildtype $\mathrm{ER} \alpha$ in the weakly ER $\alpha$-positive breast tumors are inhibited to a greater extent by the presence of ER $\Delta 7$, leaving the tumor cells with insufficient ER $\alpha$ activity to

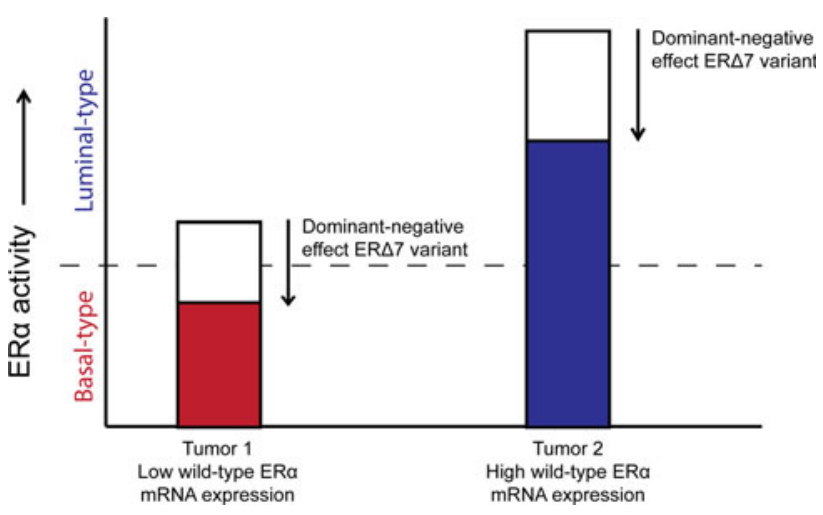

Fig. 4 Proposed model by which ER $\Delta 7$ mRNA expression can affect $\mathrm{ER} \alpha$ activity in low ER $\alpha$ wild-type expressing tumors (left) and in high ER $\alpha$ wild-type expressing tumors (right) 
regulate ER $\alpha$ target gene expression and thus with a Basal phenotype (Fig. 4, left). It remains to be explained why lower levels of ER $\alpha$ result in a relative increase in abundance of the ER $\Delta 7$ splice variant. It is possible that ER $\alpha$ also controls the expression of certain components of the splicing machinery and that low ER $\alpha$ activity therefore results in a different processing of the ER $\alpha$ (and potentially also other) precursor mRNAs.

A clinically relevant question is whether this identified group of $E R \alpha$-positive Basal-type tumors is likely to respond to hormonal therapy. The finding that ER $\alpha$ target genes are not expressed suggests that the mitogenic responses in such tumors are not driven by E2 and that such tumors would be unlikely to derive significant benefit from hormonal therapy. It was reported by Ellis et al. [26] in a cohort of postmenopausal women with clinical stage II to III ER-positive breast cancer that the single patient in their study with a basal-like intrinsic subtype was resistant to endocrine therapy. While it remains to be formally proven, there are other suggestions in the literature that the presence of ER $\Delta 7$ is associated with a lack of response to tamoxifen. Van Dijk [27] analyzed the relative ER $\Delta 7$ mRNA expression in a group of 21 primary breast tumors from postmenopausal early breast cancer patients treated with adjuvant tamoxifen. It was found that out of eleven ER $\alpha$ mRNA variants tested, only the ER $\Delta 7$ mRNA was significantly differentially expressed between primary breast tumors of patients who developed a tumor recurrence (13/21) and tumors of patients without recurrence $(8 / 21)$. Tumors from patients with a recurrence expressed on average $24 \%$ ER $\Delta 7$ mRNA (relative to wild-type ER $\alpha$ mRNA expression), while tumors from patients without recurrence expressed on average $9 \%$ ER $\Delta 7$ mRNA [27]. While it may be premature to withhold hormonal therapy from this group of ER $\alpha$-positive breast cancer patients, as this would require a large randomized outcome study, there are reasons to consider adding chemotherapy to the treatment regimen for these patients. We find that $94.5 \%$ of the ER $\alpha$ positive Basal-type breast cancer patients are high risk by the MammaPrint assay, making them potential candidates to benefit from chemotherapy based on their high recurrence risk. Moreover, Basal-type breast cancers have been shown to be significantly more responsive to neoadjuvant chemotherapy as compared to luminal breast cancers, again indicating that addition of chemotherapy could be effective in this patient group [7]. The St. Gallen consensus guidelines state that patients with an (borderline) ER $\alpha$-positive Basaltype tumor are classified as incompletely endocrine responsive [28]. This relative lack of endocrine responsiveness together with a designation of "high risk" of relapse by MammaPrint will contribute to a clinician's recommendation of whether endocrine therapy alone may be sufficient or supplementary chemotherapy may be beneficial for these patients.
Our finding that ER $\alpha$-positive Basal-type tumors are in general borderline ER $\alpha$ positive on mRNA level is in agreement with the conclusions of Iwamoto et al. who found that most of the 1-9\% IHC ER $\alpha$-positive tumors show molecular features similar to ER $\alpha$-negative basal-like tumors [17]. The strength of our study is the high number of cases and therefore the better estimate we can make of the frequency of ER $\alpha$-positive Basal-type tumors. In addition, we show that a majority of these tumors have a high-risk prognostic profile. One limitation of our study is that we do not have all the clinical information for the entire group of patients which was studied here. For instance, we did not have access to the IHC data for all the patients in this study and had to rely on TargetPrint to assess ER $\alpha$ levels. However, IHC data were available for 8 of the 12 ER $\alpha$-positive Basal type for which ER $\Delta 7$ expression was determined (Table 1) and showed that 6 of 8 tumors scored clearly positive for ER $\alpha$ protein by IHC.

ER $\alpha$-positive breast tumors have in general a better prognosis than $E R \alpha$-negative tumors [29]. In spite of this, the group of ER $\alpha$-positive Basal-type breast tumors consists nearly exclusively of high-risk patients as judged by the MammaPrint assay (Table 2). Our present data also provide a possible explanation for this finding. In contrast to the OncotypeDX ${ }^{\mathrm{TM}}$ prognostic signature, the 70-gene MammaPrint ${ }^{\mathrm{TM}}$ signature does not include $\mathrm{ER} \alpha[23,30]$. We find that 16 MammaPrint genes are responsive to E2 treatment and that 12 of these are classified as direct ER $\alpha$ targets based on ER $\alpha / \mathrm{DNA}$ associations in close proximity to the TSS, indicating that MammaPrint determines ER $\alpha$ activity rather than merely its expression. We believe that this likely explains why the first patient (Table 1, patient 1 ) having the ER $\alpha$-positive basal phenotype was characterized by the OncotypeDX assay as "low risk", but "high risk" by MammaPrint and patient 11 also had a discordant risk assessment in these two assays (Table 1). The ER $\alpha$ mRNA is expressed at a relatively high level in these patients, which is a "good prognosis" factor in the OncotypeDX assay. However, MammaPrint identified this tumor as lacking a functional $\mathrm{ER} \alpha$ and came to a "high risk" reading.

In conclusion, by combining TargetPrint and BluePrint molecular subtyping analysis, we have identified a subgroup of some $2 \%$ of breast cancer patients who lack ER $\alpha$ function while expressing ER $\alpha$ at the mRNA and protein level. Our data indicate that such patients are frequently at high recurrence risk and might benefit from adjuvant chemotherapy.

Acknowledgments We are grateful to Dr. Allen (Morton Plant Hospital), Dr. Chung (Joyne Wayne Cancer Institute Breast Center), Dr. Cox (Tampa Bay Breast Care Specialists), Dr. Greif (Alta Bates Summit Medical Center), Dr. Hunter (Comanche Country Hospital), Dr. Sachedina (Central Florida Breast Center), Dr. Schwartz (Thomas Jefferson University Hospital), Dr. Sinha (Rockwood Clinic), Dr. 
Terschluse (SSM Depaul Health Center), Dr. Weintritt (Surgical Specialists of Northern Virginia), Dr. West (The Breast Care \& Imaging Center of Orange Country), and Dr. Yao (NorthShore Hospital) for assisting in obtaining informed consent and providing clinical information. The authors thank Femke de Snoo and Lisette Stork (Agendia) for administrative support and critical reading of the manuscript. We thank Neil Barth (Agendia) for helpful suggestions on the manuscript. This work was supported by a Grant from the European Research Council (to Rene Bernards).

Conflict of interest Arno Floore and Rene Bernards are employees of Agendia NV.

Open Access This article is distributed under the terms of the Creative Commons Attribution Noncommercial License which permits any noncommercial use, distribution, and reproduction in any medium, provided the original author(s) and the source are credited.

\section{References}

1. Davies C, Godwin J, Gray R, Clarke M, Cutter D, Darby S, McGale P, Pan HC, Taylor C, Wang YC, Dowsett M, Ingle J, Peto R (2011) Relevance of breast cancer hormone receptors and other factors to the efficacy of adjuvant tamoxifen: patient-level meta-analysis of randomised trials. Lancet 378(9793):771-784. doi:10.1016/S0140-6736(11)60993-8

2. Sommer S, Fuqua SA (2001) Estrogen receptor and breast cancer. Semin Cancer Biol 11(5):339-352. doi:10.1006/scbi.2001.0389

3. Hah N, Danko CG, Core L, Waterfall JJ, Siepel A, Lis JT, Kraus WL (2011) A rapid, extensive, and transient transcriptional response to estrogen signaling in breast cancer cells. Cell 145(4):622-634. doi:10.1016/j.cell.2011.03.042

4. Carroll JS, Meyer CA, Song J, Li W, Geistlinger TR, Eeckhoute J, Brodsky AS, Keeton EK, Fertuck KC, Hall GF, Wang Q, Bekiranov S, Sementchenko V, Fox EA, Silver PA, Gingeras TR, Liu XS, Brown M (2006) Genome-wide analysis of estrogen receptor binding sites. Nat Genet 38(11):1289-1297

5. Dowsett M, Cuzick J, Ingle J, Coates A, Forbes J, Bliss J, Buyse M, Baum M, Buzdar A, Colleoni M, Coombes C, Snowdon C, Gnant M, Jakesz R, Kaufmann M, Boccardo F, Godwin J, Davies C, Peto R (2010) Meta-analysis of breast cancer outcomes in adjuvant trials of aromatase inhibitors versus tamoxifen. J Clin Oncol Official J Am Soc Clin Oncol 28(3):509-518. doi:10.1200/ JCO.2009.23.1274

6. Perou CM, Sorlie T, Eisen MB, van de Rijn M, Jeffrey SS, Rees CA, Pollack JR, Ross DT, Johnsen H, Akslen LA, Fluge O, Pergamenschikov A, Williams C, Zhu SX, Lonning PE, Borresen-Dale AL, Brown PO, Botstein D (2000) Molecular portraits of human breast tumours. Nature 406(6797):747-752. doi:10. $1038 / 35021093$

7. Krijgsman O, Roepman P, Zwart W, Carroll JS, Tian S, de Snoo FA, Bender RA, Bernards R, Glas AM (2012) A diagnostic gene profile for molecular subtyping of breast cancer associated with treatment response. Breast Cancer Res Treat 133(1):37-47. doi:10.1007/s10549-011-1683-z

8. Zhang QX, Borg A, Fuqua SA (1993) An exon 5 deletion variant of the estrogen receptor frequently coexpressed with wild-type estrogen receptor in human breast cancer. Cancer Res 53(24):5882-5884

9. Fuqua SA, Fitzgerald SD, Chamness GC, Tandon AK, McDonnell DP, Nawaz Z, O’Malley BW, McGuire WL (1991) Variant human breast tumor estrogen receptor with constitutive transcriptional activity. Cancer Res 51(1):105-109

10. Fuqua SA, Fitzgerald SD, Allred DC, Elledge RM, Nawaz Z, McDonnell DP, O’Malley BW, Greene GL, McGuire WL (1992)
Inhibition of estrogen receptor action by a naturally occurring variant in human breast tumors. Cancer Res 52(2):483-486

11. Herynk MH, Fuqua SA (2004) Estrogen receptor mutations in human disease. Endocr Rev 25(6):869-898. doi:10.1210/er.20030010

12. McGuire WL, Chamness GC, Fuqua SA (1991) Estrogen receptor variants in clinical breast cancer. Mol Endocrinol 5(11): 1571-1577

13. Hammond ME, Hayes DF, Dowsett M, Allred DC, Hagerty KL, Badve S, Fitzgibbons PL, Francis G, Goldstein NS, Hayes M, Hicks DG, Lester S, Love R, Mangu PB, McShane L, Miller K, Osborne CK, Paik S, Perlmutter J, Rhodes A, Sasano H, Schwartz JN, Sweep FC, Taube S, Torlakovic EE, Valenstein P, Viale G, Visscher D, Wheeler T, Williams RB, Wittliff JL, Wolff AC (2010) American Society of Clinical Oncology/College of American Pathologists guideline recommendations for immunohistochemical testing of estrogen and progesterone receptors in breast cancer. Arch Pathol Lab Med 134(6):907-922. doi:10. 1043/1543-2165-134.6.907

14. Garcia Pedrero JM, Zuazua P, Martinez-Campa C, Lazo PS, Ramos S (2003) The naturally occurring variant of estrogen receptor (ER) ERDeltaE7 suppresses estrogen-dependent transcriptional activation by both wild-type ERalpha and ERbeta. Endocrinology 144(7):2967-2976

15. Harvey JM, Clark GM, Osborne CK, Allred DC (1999) Estrogen receptor status by immunohistochemistry is superior to the ligand-binding assay for predicting response to adjuvant endocrine therapy in breast cancer. J Clin Oncol Official J Am Soc Clin Oncol 17(5):1474-1481

16. Chia SK, Bramwell VH, Tu D, Shepherd LE, Jiang S, Vickery T, Mardis E, Leung S, Ung K, Pritchard KI, Parker JS, Bernard PS, Perou CM, Ellis MJ, Nielsen TO (2012) A 50-gene intrinsic subtype classifier for prognosis and prediction of benefit from adjuvant tamoxifen. Clin Cancer Res Official J Am Assoc Cancer Res 18(16):4465-4472. doi:10.1158/1078-0432.CCR-12-0286

17. Iwamoto T, Booser D, Valero V, Murray JL, Koenig K, Esteva FJ, Ueno NT, Zhang J, Shi W, Qi Y, Matsuoka J, Yang EJ, Hortobagyi GN, Hatzis C, Symmans WF, Pusztai L (2012) Estrogen receptor (ER) mRNA and ER-related gene expression in breast cancers that are $1 \%$ to $10 \%$ ER-positive by immunohistochemistry. J Clin Oncol 30(7):729-734. doi:10.1200/JCO.2011. 36.2574

18. Roepman P, Horlings HM, Krijgsman O, Kok M, Bueno-deMesquita JM, Bender R, Linn SC, Glas AM, van de Vijver MJ (2009) Microarray-based determination of estrogen receptor, progesterone receptor, and HER2 receptor status in breast cancer. Clin Cancer Res Official J Am Assoc Cancer Res 15(22): 7003-7011. doi:10.1158/1078-0432.CCR-09-0449

19. Glas AM, Floore A, Delahaye LJ, Witteveen AT, Pover RC, Bakx N, Lahti-Domenici JS, Bruinsma TJ, Warmoes MO, Bernards R, Wessels LF, Van't Veer LJ (2006) Converting a breast cancer microarray signature into a high-throughput diagnostic test. BMC Genomics 7:278. doi:10.1186/1471-2164-7-278

20. Fullwood MJ, Liu MH, Pan YF, Liu J, Xu H, Mohamed YB, Orlov YL, Velkov S, Ho A, Mei PH, Chew EG, Huang PY, Welboren WJ, Han Y, Ooi HS, Ariyaratne PN, Vega VB, Luo Y, Tan PY, Choy PY, Wansa KD, Zhao B, Lim KS, Leow SC, Yow JS, Joseph R, Li H, Desai KV, Thomsen JS, Lee YK, Karuturi RK, Herve T, Bourque G, Stunnenberg HG, Ruan X, CacheuxRataboul V, Sung WK, Liu ET, Wei CL, Cheung E, Ruan Y (2009) An oestrogen-receptor-alpha-bound human chromatin interactome. Nature 462(7269):58-64. doi:10.1038/nature08497

21. Schmidt D, Wilson MD, Spyrou C, Brown GD, Hadfield J, Odom DT (2009) ChIP-seq: using high-throughput sequencing to discover protein-DNA interactions. Methods 48(3):240-248. doi:10. 1016/j.ymeth.2009.03.001 
22. Ross-Innes CS, Stark R, Teschendorff AE, Holmes KA, Ali HR, Dunning MJ, Brown GD, Gojis O, Ellis IO, Green AR, Ali S, Chin SF, Palmieri C, Caldas C, Carroll JS (2012) Differential oestrogen receptor binding is associated with clinical outcome in breast cancer. Nature 481(7381):389-393. doi:10.1038/nature10730

23. van 't Veer LJ, Dai H, van de Vijver MJ, He YD, Hart AA, Mao M, Peterse HL, van der Kooy K, Marton MJ, Witteveen AT, Schreiber GJ, Kerkhoven RM, Roberts C, Linsley PS, Bernards R, Friend SH (2002) Gene expression profiling predicts clinical outcome of breast cancer. Nature 415(6871):530-536. doi:10. 1038/415530a

24. Zwart W, Theodorou V, Kok M, Canisius S, Linn S, Carroll JS (2011) Oestrogen receptor-co-factor-chromatin specificity in the transcriptional regulation of breast cancer. EMBO J 30(23): 4764-4776. doi:10.1038/emboj.2011.368

25. Nielsen TO, Hsu FD, Jensen K, Cheang M, Karaca G, Hu Z, Hernandez-Boussard T, Livasy C, Cowan D, Dressler L, Akslen LA, Ragaz J, Gown AM, Gilks CB, van de Rijn M, Perou CM (2004) Immunohistochemical and clinical characterization of the basal-like subtype of invasive breast carcinoma. Clin Cancer Res Official J Am Assoc Cancer Res 10(16):5367-5374. doi:10.1158/ 1078-0432.CCR-04-0220

26. Ellis MJ, Suman VJ, Hoog J, Lin L, Snider J, Prat A, Parker JS, Luo J, DeSchryver K, Allred DC, Esserman LJ, Unzeitig GW,
Margenthaler J, Babiera GV, Marcom PK, Guenther JM, Watson MA, Leitch M, Hunt K, Olson JA (2011) Randomized phase II neoadjuvant comparison between letrozole, anastrozole, and exemestane for postmenopausal women with estrogen receptor-rich stage 2 to 3 breast cancer: clinical and biomarker outcomes and predictive value of the baseline PAM50-based intrinsic subtypeACOSOG Z103. J Clin Oncol Official J Am Soc Clin Oncol 29(17):2342-2349. doi:10.1200/JCO.2010.31.6950

27. van Dijk MA (2001) Functional activity of human estrogen receptor alpha in normal breast tissue and breast cancer. Dissertation, Free University, Amsterdam, The Netherlands

28. Goldhirsch A, Glick JH, Gelber RD, Coates AS, Thurlimann B, Senn HJ (2005) Meeting highlights: international expert consensus on the primary therapy of early breast cancer. Ann Oncol Official J ESMO 16(10):1569-1583. doi:10.1093/annonc/mdi326

29. McGuire WL (1991) Breast cancer prognostic factors: evaluation guidelines. J Natl Cancer Inst 83(3):154-155

30. Paik S, Shak S, Tang G, Kim C, Baker J, Cronin M, Baehner FL, Walker MG, Watson D, Park T, Hiller W, Fisher ER, Wickerham DL, Bryant J, Wolmark N (2004) A multigene assay to predict recurrence of tamoxifen-treated, node-negative breast cancer. N Engl J Med 351(27):2817-2826. doi:10.1056/NEJMoa041588 